\title{
The Mudharabah Implementation in Correlation Context Time Deposit
}

\author{
Asih Untari ${ }^{*}$ and Siti Ummu Adillah**) \\ ${ }^{*}$ Faculty of Law, Universitas Islam Sultan Agung (UNISSULA) Semarang, E-mail: \\ asihuntari643@gmail.com
}

${ }^{* *}$ Faculty of Law, Universitas Islam Sultan Agung (UNISSULA) Semarang, E-mail: ummu@unissula.ac.id

\begin{abstract}
Islamic banks have the function of collecting funds from customers and channeling funds for real sector activities. One of the legal bases used is Mudarabah. Mudharabah is used as a legal basis for Mudharabah Deposit products which have the aim of collecting customer funds and channeling them into the form of Mudharabah Financing. Both products are offered with a profit sharing system. In Mudharabah Deposits, the customer is a shahibul maal who will get a ratio according to the profit from the Bank. In Mudharabah Financing, the Bank as shahibul maal will get a ratio according to the profit of the Mudharib. Observing further the suitability of Islamic Bank products, especially Mudharabah Deposits and Mudharabah Financing, with the Mudharabah system in the figh literature, a sharia study of these products is compiled which is poured into this scientific paper.
\end{abstract}

Keywords: Deposit; Mudharabah; Islamic Bank.

\section{Introduction}

One of the fund-raising products offered by Islamic banks to customers is deposits. Deposit is defined as time deposits whose withdrawals can only be made within a specified period of time based on the depositing customer's agreement with the bank. ${ }^{1}$ Whereas what is meant by Mudharabah deposits are customer funds stored in banks, where the withdrawal process is based on a determined period of time, with a profit sharing system, according to a mutually agreed ratio or percentage. This time deposit is expected to be useful to meet the needs of the community/customers who are experiencing liquidity, and can also function as storage and as a vehicle for investment, because generally these products offer financial returns. The existence of Mudharabah deposits gives the public the option to choose whether to invest their funds in conventional bank

\footnotetext{
${ }^{1}$ Muhammad Firdaus, Fatwa-Fatwa Ekonomi Syariah Kontemporer, ed-1, Jakarta: Renaisan, 2005, p.44
} 
deposits whose profits refer to the prevailing interest, or Mudharabah deposits whose profits depend on the profit sharing obtained. ${ }^{2}$

As formulated in the provisions of Article 1 point 8 of Act No. 7 of 1992 as amended by Act No. 10 of 1998 Article 1 number 7 that:

"Deposits or also called time deposits are time deposits whose withdrawals can only be made at a certain time based on the depositing customer's agreement with the bank." ${ }^{3}$ Deposits are products in banks that are intended to be focused on investment interests in the form of securities, so that in Islamic banking, the principles of Mudharabah are used. In contrast to conventional banking which provides rewards with interest for depositors, in Islamic banking the rewards given to depositors are a profit sharing system of the ratio agreed at the beginning of the contract. ${ }^{4}$ In the world of banking, that profit sharing is a system that includes procedures for sharing business results between the fund provider (shahibul maal) and the fund manager (mudharib). ${ }^{5}$

The distribution of operating results can occur between banks (mudharib) and depositors of funds (shahibul maal), or between banks and bank customers receiving funds/entrepreneurs. The results of bank operations which are distributed to depositors of funds are in the form of bank operating profits which are calculated within a certain period. Meanwhile, the results of the operations of the customer receiving the funds which are shared with the bank is the operating profit generated by the customer receiving the funds from one of his businesses which is entirely financed by the bank. ${ }^{6}$ Thus profit sharing is the most common concept and there is no doubt in it, even all scholars agree with this profit sharing transaction. The presence of a profit-sharing system in Islamic banking will certainly not provide space for the profit/interest system, because the profits that are shared must be divided proportionally between the shahibul maal and the mudharib.

Banks with their respective customers benefit, the advantage for banks by collecting funds through deposits is that money is stored relatively longer,

\footnotetext{
${ }^{2}$ Ruslizar Dan Rahmawaty, "Pengaruh Tingkat Bagi Hasil Deposito Mudharabah, Financing To Deposit Ratio, Dan Suku Bunga Deposito Terhadap Pertumbuhan Deposito Mudharabah Pada Bank Umum Syariah Di Indonesia", Jurnal IImiah Mahasiswa Ekonomi Akuntansi (Jimeka)Vol. 1, No. 2, (2016), p. 84-90.

${ }^{3}$ Adiwarman A. Karim , Bank Islam, Jakarta: PT Raja Grafindo Persada, ed-7. p. 286.

${ }^{4}$ Abdul Ghofur Anshori, Perbankan Syariah Indonesia, Yogyakarta: Gadjah Mada University Press, 2009, p.71

${ }^{5}$ Muhamad, Lembaga-lembaga Keuangan Umat Kontemporer, Yogyakarta; UII Press, ed-1, 2000, p. 52

${ }^{6}$ Prof. H. A. Djazuli dan Drs. Yadi Janwari, M. Ag, Lembaga-lembaga Perekonomian Umat Sebuah Pengenalan, Jakarta; PT. Raja Grafindo Persada, ed-1, 2002, p. 63
} 
considering that deposits have a relatively long period of time and a long frequency of withdrawals. Therefore, banks will be more flexible in channeling these funds for productive activities. Meanwhile, the customer will benefit in the form of profit sharing in accordance with the ratio that has been agreed upon from the beginning of the agreement. All routine expenses related to the Mudharabah business, not for the personal benefit of the mudharib, can be included in operational costs. The net profit must be divided between the shahibul maal and the mudharib in accordance with the pre-agreed proportion and explicitly stated in the initial agreement.

Withdrawal of deposits in the form of time deposits has been determined (fixed time) and is adjusted to the agreement between the depositing customer and the bank at the time of opening the relevant deposit. The use of deposits (term deposits) is more as an investment instrument than as a place to store excess liquidity.

Substantially, sharia banking regulations also formulate the definition of deposits as stipulated in Article 1 number 22 of Act No. 21 of 2008, namely: ${ }^{7}$

"Deposit is an investment of funds based on a Mudharabah contract or other contract that does not conflict with sharia principles, the withdrawal of which can only be made at a certain time based on an agreement between the depositing customer and the sharia bank and or UUS."

Meanwhile, what is meant by investment is formulated in the provisions of Article 1 number 24 of Act No. 21 of 2008, namely:

"Investments are funds entrusted by customers to Islamic banks and or UUS based on other Mudharabah contracts that do not conflict with sharia principles in the form of deposits, savings, or other equivalent forms."

Traditionally, time deposits are a source of bank funding with a certain period of time and relatively low fluctuations in funds. Meanwhile, for customers, time deposits are an alternative investment that provides benefits to customers.

The opportunity for developing deposit features/products (time deposits) basically lies in the withdrawal period and interest with various variations. The time period for withdrawals also varies, from daily, weekly, monthly, or yearly. In the banking competition, there is a time deposit product which can be withdrawn at any time. In this context, the word term has been twisted in such a way that time deposit products have lost their meaning to almost like savings.

\footnotetext{
${ }^{7}$ Act No. 21 of 2008 concerning Sharia Banking Article 1 number 22

${ }^{8}$ Ibid, no. 24
} 
In addition to interest, aspects of opening and closing deposits (time deposits) are also necessary and are factors that can attract the sympathy of customers. With regard to the opening, there is no prohibition against the deposit being opened by a person or entity. Deposits can be opened in rupiah or foreign currency. For banks that have a good level of technology system, deposit bookkeeping can be done through the means of information technology systems. In the opening of deposits, the minimum nominal and its multiples are also regulated. In terms of withdrawal, it is determined with certainty with the deposit slip in question and based on the provisions in force at the bank concerned.

\section{Research Methods}

The method that the author uses is normative legal research, in normative legal research usually only secondary data sources are used, namely library literature books, notebooks, statutory regulations, scientific articles, court decisions, newspapers, legal theories and opinions of legal experts. ${ }^{9}$

The types of data used by the author are: Primary legal materials, namely legislation and secondary legal materials, namely legal books; literature from libraries, legal journals; Legal papers or Legal Expert Views published in the mass media (print).

Data Collection Techniques In this study, the focus of the research was on secondary data. Thus, the main activity carried out to carry out this research is library research. Secondary data is data obtained from the results of the literature, by reviewing, researching, analyzing and processing literature data, laws and regulations, articles or writings related to the issues studied by the author.

Data Analysis Techniques Analysis is an explanation of all the materials and data collected and explained systematically. The explanation is packaged logically according to the author's thoughts. In this research method there are several types of data analysis techniques, but in this study using qualitative data analysis techniques, which is a data analysis method with a system of classifying and selecting the data that has been obtained from the research, according to quality and truth then compiled conceptually and systematically, which is then studied by the method of thinking deductively connected with theories from the study of literature (secondary data) then conclusions are drawn in order to obtain

\footnotetext{
${ }^{9}$ Peter Mahmud Marzuki, Penelitian Hukum (Jakarta : Kencana,2005), p. 13.
} 
benefits to answer the problems in this study. ${ }^{10}$

\section{Result and Discussion}

The main character of deposits (time deposits) is the exact and exact time of withdrawal. Therefore, time deposits or time deposits are also called fixed deposits and generally have maturities of 1, 3, 6, 12, and 24 months. Interest will be paid each month on the day of payment or at the same time paid when the deposit is due, as agreed. In the practice of conventional banks, depositors generally open a savings account at the bank concerned, so that the deposit interest at maturity can be transferred directly to the depositor's account. However, if there is no special account, the interest on the deposit can increase the principal amount of the customer's deposit until its maturity date.

As a product of raising funds, banks will be exposed to liquidity risk, especially when deposits mature if the maturity gap between the collection and investment of funds is quite large. In addition, Islamic banks also face market risk in the form of exchange rate risk if deposits are in foreign currency. Banks are also exposed to commercial displacement risk in the form of potential customers moving their funds driven by the real profit sharing rate lower than the interest rate.

As for deposits or time deposits based on sharia principles or deposits that are justified by sharia. Deposits based on sharia principles or sharia deposits are stipulated for sharia banking through the Decree of the Board of Directors of Bank Indonesia Number 32/34/KEP/DIR concerning Commercial Banks Conducting Business Activities Based on Sharia Principles as amended by Bank Indonesia Regulation Number 7/35/PBI /2005 and also Decree of the Board of Directors of Bank Indonesia Number 32/36/Kep/Dir concerning Rural Banks Based on Sharia Principles, which was later updated and refined by Bank Indonesia Regulation Number 6/17/PBI/2004 concerning Rural Banks Based on Sharia Principles as has been amended by Bank Indonesia Regulation Number 8/25/PBI/2006 ${ }^{11}$. Furthermore, it was reaffirmed in Act No. 21 of 2008.

In contrast to the conventional banking system which provides interest rewards for depositors, in Islamic banking the rewards for depositors are in the form of profit sharing in the amount of the agreed ratio at the beginning of the agreement. In Islamic banks, the profit-sharing system can compete competitively with interest rates in banks conventional. When conventional bank interest rates increase, the profit sharing in Islamic banks becomes less competitive, as a result there will be a reduction in third party funds in Islamic

\footnotetext{
${ }^{10}$ Abdulkadir Muhammad, Hukum dan Penelitian Hukum ed-1, Bandung : PT. Citra AdityaBakti, 2004, p.50

${ }^{11}$ Bank Indonesia Regulation Number 8/25/PBI/2006
} 
banking. And vice versa if Islamic banks offer profit sharing higher than the interest rates in conventional banks, there will be an increase in third party funds in Islamic banks. ${ }^{12}$

For deposits (time deposits) this sharia is based on the principle of the Mudharabah contract, with the aim of saving funds in the form of time deposits (time deposits) to invest excess liquidity. This provision is regulated in the DSN Fatwa Number 03/DSN-MUI/IV/2000 concerning deposits. This fatwa states, if the public refers to the practice of deposits owned by conventional banks, banking services in the form of deposits are not in accordance with sharia because there is an element of usury so that it is necessary to have deposit services that are in accordance with sharia principles and do not reduce the features inherent in them in order to facilitate public affairs in financial transactions. Based on this, Deposit products that are permitted by DSN based on sharia are deposits based on the Mudharabah principle. As explained earlier, Mudharabah is a business cooperation contract between 2 (two) parties, in which the first party as the owner of the funds (shahibul maal) provides all of the working capital (100\%), while the other party becomes the fund manager (mudharib).

The type of Mudharabah is correlated with sharia deposits, In the perspective of Islamic law, there are 2 (two) types of Mudharabah, namely:

\section{Mudharabah Muthlaqah}

It is a form of cooperation between shahibul maal and mudharib whose scope is very comprehensive/broad and not limited to the specifications of the type of business, time and area of business. In a sharia banking contract, the bank has full discretion and great power in managing customer funds, there are no specific restrictions.

\section{Mudharabah Muqayyadah}

It is the opposite of Mudharabah mutlaqah. The mudharib is limited by the type of business. The existence of these restrictions often reflects the general tendency of shahibul maal in entering this type of business.

DSN through Fatwa Number 03/DSN-MUI/IV/2000 also stipulates general provisions for deposits based on the Mudharabah contract, namely: In this transaction, the customer acts as the shahibul maal or the owner of the funds

\footnotetext{
${ }^{12}$ Nila Juniarty, Mustika Noor Mifrahi, Dan Achmad Tohirin," Faktor-Faktor Yang Mempengaruhi Deposito Mudharabah Pada Bank Syariah Di Indonesia", Urnal Ekonomi \& Keuangan Islam, Vol. 3 No. 1, January 2017: 36-42
} 
and the bank acts as the mudharib or manager.In its capacity as mudharib, banks can carry out various kinds of business that do not conflict with sharia principles and develop them, including Mudharabah with other parties. Capital must be stated in terms of the amount, in cash and not receivables.Profit sharing must be stated in the form of a ratio and the profit will be in the account bookkeeping contract, Islamic banks as mudharib cover the operational costs of deposits by using the profit ratio that is their right, Islamic banks are not allowed to reduce the customer's profit ratio without the relevant approval. In line with the fatwa of the DSN as mentioned above, the provisions in article 5 of bank indonesia regulation number $7 / 46 / \mathrm{PBI} / 2005$ stipulates the minimum requirements for fundraising activities in the form of deposits based on Mudharabah, as follows:

a. Islamic banks act as fund managers while customers act as fund owners.

b. Funds are paid in full to Islamic banks and stated in the amount (nominal).

c. Some of the benefits of managing investment funds are expressed in the form of a ratio.

d. Islamic banks which as mudharib cover the operational costs of deposits by using the profit ratio that is their right.

e. Islamic banks are prohibited from reducing the customer's profit share without the consent of the customer concerned.

f. Islamic banks do not guarantee customer funds, unless regulated differently in the applicable legislation.

Similarly, the provisions regarding the minimum requirements for fundraising activities in the form of deposits on the basis of the Mudharabah contract are rearranged in the circular letter of Bank Indonesia Number 10/14/DPbS dated March 17, 2008:The bank acts as a fund manager (mudharib) and the customer acts as the owner of the funds (shahibul maal), fund management by banks can be carried out according to the limitations set by the fund owner (mudharab muqayyad) or carried out without restrictions from the fund owner (mudharab mutlaqah).Banks are required to explain to customers about product characteristics, as well as customer rights and obligations as stipulated in banka indonesia regulations regarding transparency of bank product information and the use of customer personal data,Banks and customers are required to enter into an agreement on the opening and use of deposit products on the basis of a Mudharabah contract, in the form of a written agreement. In the Mudharabah muqayyadah contract, it must be clearly stated that certain conditions and limitations have been determined by the customer.Profit sharing is expressed in the form of an agreed ratio. Withdrawal of funds by customers can only be done according to the agreed time, Banks may charge customers administrative fees in the form of costs directly related to account management costs, including stamp duty fees, printing of transaction reports and account balances, account opening 
and closing. Banks are not allowed to reduce the customer's profit share without the consent of the customer concerned.

When compared with deposits that use the principle of fixed interest, it is much different from deposits that use the principle of no interest. In the interest system, the depositor's customer will receive a certain interest in a fixed and periodic cycle, regardless of the efforts made by the sharia bank, whether it is a loss or a profit. In Mudharabah deposits, the amount of return that will be received by the customer depends on the business carried out by the bank, namely a certain ratio or percentage of the total business carried out by the bank. The bank as mudharib does not have a permanent obligation to provide a return in a certain amount, but depends on the results of the business carried out. This contract is more appropriate to use because it is in accordance with the characteristics of a business that has the potential for profit or loss.

Fund Features, Mechanisms And Analysis of Sharia Deposits, Time deposits are deposits that can only be withdrawn at a certain time based on an agreement between the depositing customer and the bank. Purpose or Benefit, for Banks, it is traditionally a source of bank funding with relatively low terms and fluctuations of funds, For customers, it is an investment alternative that provides benefits to customers in the form of profit sharing.

Risk Analysis and Identification, sAs a fund-raising product, banks will be exposed to liquidity risk, especially when the deposit matures if the maturity gap between fundraising and investment is large. In addition, banks also face market risk in the form of exchange rate risk (if deposits are in foreign currency). Banks are also exposed to commercial displacement risk in the form of the potential for customers to move their funds driven by the real profit sharing rate that is lower than the interest rate.

Fatwa of the National Sharia Council No: 03/DSN-MUI/IV/2000 regarding deposits ${ }^{13}$. Deposits that are justified by Sharia, namely deposits based on the principles of Mudharabah with general provisions, namely, In this transaction, the customers act as shahibul maal or fund owners, and the bank acts as mudharib or fund manager.In terms of its capacity as a mudharib, the bank can carry out various types of business that do not conflict with sharia principles (according to Islamic sharia) and develop its business, including Mudharabah in connection with other parties, Capital must be stated by the amount, in cash and not a receivable system. Profit sharing must be stated in the form of a ratio and stated in the account bookkeeping contract. Bank as mudharib covers the operating costs of demand deposits by using the profit ratio that is their right,Banks are not used to reduce the customer's profit ratio without the relevant approval.

${ }^{13}$ Fatwa of the National Sharia Council No: 03/DSN-MUI/IV/2000 regarding deposits 
BRI Deposit is a deposit product that provides security in your fund investment. Advantages:Safe investment services from trusted banks, Intended for individual customers and business entities/companies, Real Time On-Line, able to transact online in more than 2,000 BRI work units on-line throughout Indonesia,Freedom to choose currency: Rupiah, USD, EUR, SGD, JPY, The flexibility to choose the time period starting from Deposit On Call with a period of 1,2,3,6,12, 18, and 24 months, Free administration fee, Can be used as collateral for BRI credit,Disbursement of part of the nominal BRI Deposit without changing the account number, Disbursement of BRI Deposits in other BRI work units, Attractive and competitive interest rates.

Facility, automatic roll-over can be done. At maturity, customers are free to enjoy interest on: Cash, Transferred to another account at BRI, Transferred/cleared account to another bank, increase the principal of the BRI Deposit at the time of extension (add-on).

Bookkeeping TermsFill out the BRI Deposit bookkeeping form. Minimum deposit according to the provisions for each currency. For individual customers, attach a photocopy of their identity card (KTP/SIM/Passport/KITAS/KITAS.

\section{Closing}

Based on the results of the analysis above, it can be concluded that the application of the Mudharabah deposit mechanism on sharia savings products has conditions and distribution of profit sharing for Mudharabah deposits. The existing Mudharabah deposit mechanism acts as a fund manager (mudharib) and the customer as the owner of the funds (shahibul maal). Withdrawal of funds by the customer can only be done at a certain time based on the contract between the customer and the Islamic Bank. Profit sharing is in accordance with the initial agreement between the Islamic bank and the customer.

\section{References}

Journal:

[1] Ruslizar Dan Rahmawaty, "Pengaruh Tingkat Bagi Hasil Deposito Mudharabah, Financing To Deposit Ratio, Dan Suku Bunga Deposito Terhadap Pertumbuhan Deposito Mudharabah Pada Bank Umum Syariah Di Indonesia", Jurnal IImiah Mahasiswa Ekonomi Akuntansi (Jimeka) Vol. 1, No. 2, (2016)

[2] Nila Juniarty, Mustika Noor Mifrahi, Dan Achmad Tohirin," Faktor-Faktor Yang Mempengaruhi Deposito Mudharabah Pada Bank Syariah Di Indonesia", Urnal Ekonomi \& Keuangan Islam, Vol. 3 No. 1, January 2017 Books: 
[1] Abdul Ghofur Anshori, Perbankan Syariah Indonesia, Yogyakarta: Gadjah Mada University Press, 2009.

[2] Abdulkadir Muhammad, Hukum dan Penelitian Hukum ed. I, Bandung: PT. Citra AdityaBakti, 2004.

[3] Adiwarman A. Karim, Bank Islam, Jakarta: PT Raja Grafindo Persada, Cet.7.

[4] Muhamad, Lembaga-lembaga Keuangan Umat Kontemporer, Yogyakarta; UII Press, ed-1, 2000.

[5] Muhammad Firdaus, Fatwa-Fatwa Ekonomi Syariah Kontemporer, ed-1, Jakarta: Renaisan, 2005

[6] Peter Mahmud Marzuki, Penelitian Hukum (Jakarta: Kencana, 2005

[7] Prof. H. A. Djazuli dan Drs. Yadi Janwari, M. Ag, Lembaga-lembaga Perekonomian Umat Sebuah Pengenalan, Jakarta; PT. Raja Grafindo Persada, ed-1, 2002.

Regulations:

[1] Act No. 21 of 2008 concerning Sharia Banking

[2] Bank Indonesia Regulation Number 8/25/PBI/2006

[3] Fatwa of the National Sharia Council No: 03/DSN-MUI/IV/2000 regarding deposits 